\title{
Evaluation of the Predictive Value of Left Anterior Fascicular Block on Determination of Left Main and/or Proximal Left Anterior Descending Coronary Artery Disease in Patients with Stable Angina: A Propensity Score Matching Analysis
}

\author{
Sol Anterior Fasiküler Bloğun Stabil Anginalı Hastalarda Sol Ana ve/veya Proksimal \\ Sol Ön İnen Koroner Arter Hastalığının Belirlenmesinde Öngördürücü Değerinin \\ Araștırılması: Bir Eğilim Skoru Eșleștirme Analizi
}

\author{
(1) Ömer Faruk Çırakoğlu11, (1) Sinan Şahin¹, (1) Ahmet Seyda Yılmaz² \\ 1Trabzon Ahi Evren Thoracic and Cardiovascular Surgery Training and Research Hospital, Clinic of Cardiology, Trabzon, Turkey \\ ${ }^{2}$ Recep Tayyip Erdoğan University Faculty of Medicine, Department of Cardiology, Rize, Turkey
}

\begin{abstract}
Introduction: Successful revascularization of lesions located in the left main and/or proximal left anterior descending (LM and/or pLAD) coronary artery improves survival than medical therapy only. Therefore, accurate identification of highrisk patients with suspected stable angina pectoris is critical for outpatient clinics. Since the septal perforators of the left anterior descending coronary artery are the main source of blood supply of the left anterior fascicle, we hypothesized that the presence of left anterior fascicular block (LAFB) can predict obstructive stenoses of LM and/or pLAD coronary arteries in patients with suspected stable angina pectoris.

Methods: We consecutively enrolled 790 patients referred for invasive coronary angiography due to suspected stable angina pectoris.

Results: The number of patients with LAFBs was 68 (8.6\%). Furthermore, 218 patients (27.6\%) had obstructive coronary artery disease (CAD). The prevalence of obstructive CAD, revascularization with coronary artery bypass graft surgery, and obstructive LM and/or pLAD coronary artery lesions was higher in patients with LAFB. From univariate analysis, the presence of LAFB was significantly associated with predicting obstructive LM and/or pLAD lesions (odds ratio: 3,587; 95\% confidence interval: $1,465-5,785 ; p=0.005)$. However, this association disappeared after adjustment for other cardiovascular risk factors.

Conclusion: In patients with suspected stable angina pectoris, LAFB is not frequently a "normal variant" and is associated with known cardiovascular risk factors. It acts as a marker rather than a determinant of obstructive LM and/or pLAD coronary artery lesions.

Keywords: Left anterior fascicular block, obstructive left main coronary artery lesion, obstructive proximal left anterior descending coronary artery lesion, stable angina pectoris
\end{abstract}

\section{öZ}

Amaç: Sol ana ve/veya proksimal sol ön inen (LM ve/veya pLAD) koroner arterde yer alan lezyonların başarılı revaskülarizasyonu, yalnızca medikal tedaviye kıyasla sağkalımı artırmaktadır. Bu nedenle, stabil angina pektoris şüphesi olan hastalarda bu bölgelerdeki kritik darlıklar için yüksek riskli hastaların saptanması önemlidir. Sol ön inen koroner arterin septal perforatörleri, sol anterior fasikülün ana kan besleme kaynağı olduğundan, stabil angina pektoris șüphesi olan hastalarda sol anterior fasiküler blok (LAFB) varlığının, LM ve/veya $\mathrm{pLAD}$ koroner arterlerinin obstrüktif stenozlarını öngörebileceği hipotez olarak düşünüldü.

Yöntemler: Stabil anjina pektoris şüphesi nedeniyle invaziv koroner anjiyografi için sevk edilen ardışı 790 hasta çalıșmaya alındı.

Bulgular: LAFB'li hasta sayısı $68(\% 8,6)$ idi. Ayrıca 218 hastada $(\% 27,6)$ obstrüktif koroner arter hastalığı saptandı. LAFB'li hastalarda; obstrüktif koroner arter hastalı̆̆ı, koroner arter by pass greft cerrahisi ile revaskülarizasyon tedavisi ve obstrüktif LM ve/veya PLAD koroner arter lezyonu prevalansı daha yüksekti. LAFB'nin varlığı, tek değişkenli analizde obstrüktif LM ve/veya pLAD lezyonlarını öngörmede istatiksel olarak önemli bir değișkendi (odds ratio: 3.587; \%95 güven aralı̆ı: 1.4655.785; $p=0,005)$. Ancak bu ilişki, diğer kardiyovasküler risk faktörleri için düzeltme yapıldıktan sonra ortadan kalktı.

Sonuç: Stabil anjina pektoris şüphesi olan hastalarda LAFB "normal bir variant" değildir ve bilinen kardiyovasküler risk faktörleri ile ilişkilidir, ancak obstrüktif LM ve/veya pLAD koroner arter lezyonunun bağımsız bir yordayıcısı olmaktan çok bir belirteç görevi görmektedir.

Anahtar Kelimeler: Sol anterior fasiküler blok, obstrüktif sol ana koroner arter lezyonu, obstrüktif proksimal sol ön inen koroner arter lezyonu, stabil angina pektoris 


\section{Introduction}

Coronary artery disease (CAD) is the primary source of disability and even death worldwide (1). The World Health Organization estimates that CAD mortality will reach 23.4 million in 2030 (2). The most frequent presentation of ischemic heart disease is chronic stable angina (3). Diagnostic algorithms based on history, physical examinations, and electrocardiograms are well established. While invasive coronary angiography (ICA) has been considered the "gold standard" test for the detection of CAD, it is invasive and has also potential disadvantages such as predisposure to cerebrovascular events, bleeding, and even death (4). In patients without unstable conditions, current guidelines stipulate the first-line use of non-invasive tests to define the need for invasive tests such as coronary angiography, especially in patients with intermediate pre-test probability (5). Depending on patient selection, the predictive values of current pre-test probability models are still not optimal. In addition, obstructive coronary lesions are found in $41 \%$ of patients with positive results from non-invasive tests (6). Since successful revascularization of lesions in the left main and/or proximal left anterior descending (LM and/or pLAD) coronary artery improves survival when compared with medical therapy only, the accurate identification of high-risk patients with stable angina pectoris is crucial. Using costeffective, easy obtainable, and non-invasive methods that can detect an obstructive LM and/or pLAD coronary arteries may be beneficial in clinical practice. Electrocardiography (ECG) is still an important part of the initial evaluation of patients presenting with cardiac complaints, despite its existence that spans out more than a century. Left anterior fascicular block (LAFB), an ECG pattern representing failure or delay of conduction in the left anterior fascicle, was initially defined as left anterior hemiblock by Rosenbaum et al. $(7,8)$. Although there are conflicting results in different study populations regarding the clinical importance of LAFB (9-14), CAD remains one of the most common causes of LAFB (15). The His bundle splits into the two bundle branches at the fibrous and muscular boundaries joint of the interventricular septum. Then, the left bundle branch gives an anterior, posterior, and, in some cases, septal fascicles. The left anterior fascicle is nourished by the septal perforators from the LAD coronary artery mainly and therefore, is more sensitive to ischemia. Since the septal perforators of the LAD coronary artery are the main source of blood supply for the left anterior fascicle, we hypothesized that the presence of LAFB can predict obstructive stenoses of the LM and/or pLAD coronary arteries in patients with stable angina pectoris.

\section{Methods}

\section{Study Population}

We included 790 consecutively enrolled patients with stable angina pectoris and referred to ICA between September 2016 and January 2020. Each patient was included doing a coronary angiography. Those with angina pectoris and complaints equivalent to angina were considered eligible for the study. Afterward, a detailed medical history and at least one non-invasive diagnostic test was performed by an experienced cardiologist to determine CAD. Patients with acute coronary syndrome, history of CAD and cardiovascular consequence, malignancy, congenital heart disease, moderate-to-severe liver and/or renal diseases, acute or chronic inflammatory diseases, moderate-to-severe valvular heart disease, and cardiomyopathies were excluded from the study as well as those with preexisting right bundle branch block (RBBB), left bundle branch block (LBBB), pace rhythm, pre-excitation syndromes, and associated ischemic ST-T abnormalities. Sociodemographic and medical history parameters were recorded. Included patients were separated into two groups depending on the occurrence of LAFB. Patients were also grouped according to the presence of obstructive LM and/or pLAD lesions.

Informed consent was granted by all patients before enrollment. The approval form the Clinical Research Ethics Committee of University of Health Sciences Turkey, Kanuni Sultan Süleyman Training and Research Hospital was obtained (approval number: 2020/62, date: 12.11.2020).

\section{Electrocardiographic Evaluation}

A standard surface 12-lead electrocardiogram ECG, with a paper speed of $25 \mathrm{~mm} / \mathrm{s}$ and a voltage of $10 \mathrm{~mm} / \mathrm{mV}$ was employed for investigations (Nihon Kohden, cardiofax GEM, ECG-9020K, Japan). All ECGs were recorded and analyzed by one experienced cardiologist blinded to the clinical data of the participants. LAFB was defined according to specified criteria: 1) QRS axis on frontal plan between -45 and -90 degrees, 2) qR pattern in lead aVL 3) R-peak time in lead aVL of 45 ms or more 4) QRS duration less than $120 \mathrm{~ms}$ (16).

\section{Coronary Angiography and Echocardiography}

Trans-radial or trans-femoral Judkins techniques were used to explore the coronary arteries in all patients. Obtained fluoroscopic images were judged by an experienced interventional cardiologist. Patients were categorized as individuals without $C A D$, with mild $C A D$, with significant CAD, and with obstructive CAD. Mild CAD was considered if lumendiameter narrowing was less than $50 \%$ within any epicardial coronaries. In addition, significant CAD was accepted as lumen-diameter narrowing of more than $50 \%$ within any epicardial coronaries. Lastly, obstructive CAD was described as a lumen-diameter narrowing of more than $50 \%$ of the LM coronary artery or narrowing $\geq 70 \%$ within any epicardial coronaries. SYNTAX scores (version 2.28) were calculated in arteries with $\geq 1.5 \mathrm{~mm}$ diameter and have luminal obstruction $\geq 50 \%$. Decisions related to revascularization strategies were made based on the preference of the attending physicians.

Transthoracic echocardiography (Philips Epiq 7 systems, Andover, MA) was performed on all participants at the time of their first examination. The left ventricular ejection fraction (LVEF) was obtained using the modified Simpson's method (17). Left ventricular hypertrophy (LVH) was equally detected by calculating the left ventricular mass (LVM) according to the Devereux formula (18). The LVM index (LVMI) was then derived by correcting the LVM for body surface area.

\section{Statistical Analysis}

Statistical analysis was performed using SPSS version 22.0 (SPSS Inc. Chicago, Illinois, USA). Continuous variables were evaluated for normality distribution using the Kolmogorov-Smirnov test. If variables were normally distributed, they were expressed as the means \pm standard deviation. Whereas, if the distribution was not normal, variables were expressed as median and inter-quartile ranges. However, categorical variables were expressed as numbers and percentages and 
were compared using the chi-square test. An Independent sample t-test was employed for parametric variables, whiel the Mann-Whitney $U$ test was employed for non-parametric variables. Propensity scores for all individuals were estimated using a logistic regression model including age, sex, occurrence of diabetes mellitus (DM), hypertension and dyslipidemia, current smoking, and family history of CAD. A 1:1 nearest neighbor matching was performed with a caliper width of 0.2 . The score-matched pairs were reanalyzed. A logistic regression analysis was performed to predict the presence of obstructive LM and/or pLAD lesions. First, we separately analyzed the relationships between the dependent variable and risk factors for CAD and LAFB. The variables that have $p$-value of $<0.1$ in a univariate regression analysis were included in the multivariate logistic regression analysis (forced entry method). A p-value $<0.05$ (2-tailed) was considered statistically significant.

\section{Results}

We observed that 750 patients (94.9\%) undertook at least one noninvasive test, and 40 patients (5.1\%) were referredfor ICA directly (Table 1). The median age was 58 years old and 532 (67.3\%) of them were males. The number of patients with LAFB was 68 (8.6\%). Furthermore, 218 patients (27.6\%) had obstructive CAD and had been treated with $\mathrm{PCl}$, coronary artery bypass graft, or optimal medical therapy alone (18.5\%, $7.6 \%$, and $1.5 \%$, respectively). The prevalence of obstructive CAD and CABG use was significantly different across LAFB and non-LAFB. Also, the prevalence of obstructive LM and/or pLAD lesions was higher in patients with LAFB. Patients with LAFB had a significantly higher LVMI. The prevalence of LAFB increased with increasing LVH grades (19) (Figure 1). Patients with obstructive LM and/or pLAD lesions were older and had a higher prevalence of hypertension, DM, dyslipidemia, family history of CAD, and LAFB (Table 2).

After propensity score matching (68 vs 68 patients), the age, sex, DM, smoking status, hypertension, dyslipidemia, family history of CAD were similar between groups (Table 3). The obstructive LM and/or pLAD lesion rate remained significantly higher in patients with LAFB [8 (11.8\%) vs 22 (32.2\%), $p=0.004$ ].

In univariate analyses, the presence of LAFB was a significant predictor of obstructive LM and/or pLAD lesions (odds ratio: 3,587; 95\% confidence interval: 1,465-5,785; $p=0.005)$. Multivariate logistic regression analysis, using significant parameters obtained from univariate analysis, was conducted to reveal independent predictors of obstructive LM and/ or pLAD lesions. A history of hypertension and DM were found to be independent predictors of obstructive LM and/or pLAD lesions. Although there was a significant relationship between the presence of LAFB and dependent variable in univariate logistic regression models, only known cardiovascular risk factors showed a direct significant association after adjusting for confounders. Thus, the presence of LAFB was not an independent predictor of obstructive LM and/or pLAD lesions (Table 4).

\section{Discussion}

We aimed at assessing the relationship between LAFB and obstructive LM and/or pLAD lesions in patients referred to ICA with stable angina pectoris. The cross-sectional analysis of our study revealed an association between the presence of LAFB and obstructive LM and/or pLAD lesions, advanced age, prevalence of dyslipidemia, and LVMI. Even though LAFB had a significant predictive value from univariate analysis, this

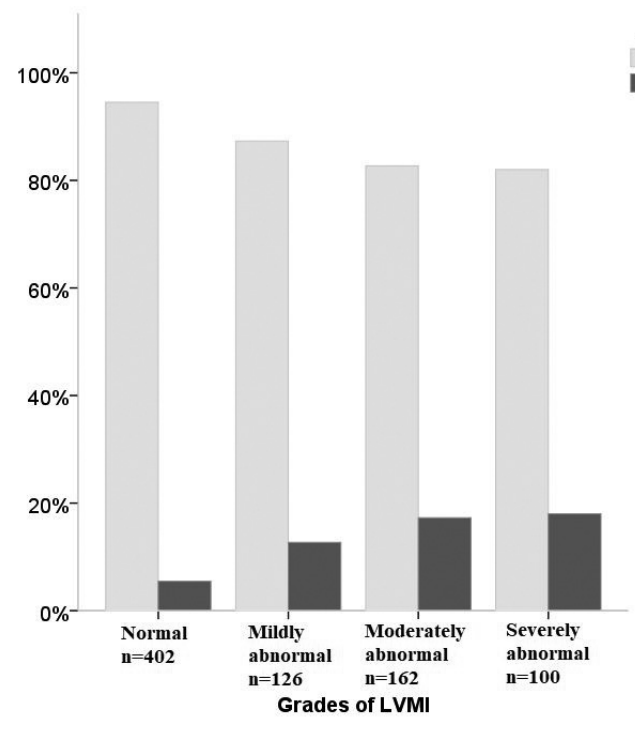

Figure 1. The plots show an upward trend in LAFB presence in line with increasing LVMI grades

LAFB: Left anterior fascicular block, LVMI: Left ventricular mass index

Table 1. Characteristics of symptoms and diagnostic tests of study population

\begin{tabular}{|c|c|c|c|}
\hline & All patients $(n=790)$ & Female $(n=258)$ & Male $(n=532)$ \\
\hline \multicolumn{4}{|c|}{ Initial diagnostic test } \\
\hline Exercise ECG & $206(26.1 \%)$ & $52(20.2 \%)$ & $154(28.9 \%)$ \\
\hline CCTA & $378(47.8 \%)$ & $128(49.6 \%)$ & $250(47 \%)$ \\
\hline MPI & $166(21 \%)$ & $66(25.6 \%)$ & $100(18.8 \%)$ \\
\hline ICA & $40(5.1 \%)$ & $12(4.6 \%)$ & $28(5.3 \%)$ \\
\hline \multicolumn{4}{|c|}{ Result of non-invasive testing } \\
\hline Positive & $258(32.7 \%)$ & $66(25.6 \%)$ & $192(36.1 \%)$ \\
\hline Negative & $466(59 \%)$ & $174(67.4 \%)$ & $292(54.9 \%)$ \\
\hline Inconclusive & $66(8.4 \%)$ & $18(7 \%)$ & $48(9 \%)$ \\
\hline Obstructive CAD & $218(27.6 \%)$ & $54(20.9 \%)$ & $164(31 \%)$ \\
\hline
\end{tabular}

CAD: Coronary artery disesae; CCTA: Coronary computed tomography angiography; ECG: Electrocardiogram; ICA: Invasive coronary angiography; MPI: Myocardial perfusion imaging 
Table 2. Baseline characteristics and laboratory findings of study population according to the presence of obstructive LM and/or pLAD lesion

\begin{tabular}{|c|c|c|c|c|}
\hline Baseline characteristics & All patients $(n=790)$ & $\begin{array}{l}\text { Obstructive LM and/or pLAD } \\
\text { lesion }-(n=652)\end{array}$ & $\begin{array}{l}\text { Obstructive LM and/or pLAD } \\
\text { lesion }+(n=138)\end{array}$ & $\mathbf{p}$ \\
\hline Age (years) & $58(50-65)$ & $58(48-64)$ & $63(57-65)$ & $<0.001$ \\
\hline Male gender, (n, \%) & $532(67.3)$ & $219(67.2)$ & 47 (68.1) & 0.831 \\
\hline Diabetes mellitus, (n, \%) & $256(32.4)$ & $102(31.3)$ & $29(42)$ & $<0.001$ \\
\hline Current smoking, (n, \%) & $310(39.2)$ & $132(40.5)$ & $27(39.1)$ & 0.680 \\
\hline Hypertension, (n, \%) & $240(30.4)$ & $164(50.3)$ & $55(79.7)$ & 0.001 \\
\hline Family history of CAD, $(n, \%)$ & $240(30.4)$ & $87(26.7)$ & $34(49.3)$ & $<0.001$ \\
\hline $\mathrm{BMI}\left(\mathrm{kg} / \mathrm{m}^{2}\right)$ & $29.4(27-33.7)$ & $29.4(26.6-34.2)$ & $30.4(27.7-31.6)$ & 0.306 \\
\hline $\mathrm{BSA}\left(\mathrm{m}^{2}\right)^{\dagger}$ & $1.96(1.85-2.07)$ & $1.96(1.86-2.07)$ & $1.92(1.84-2.06)$ & 0.118 \\
\hline LAFB, (n, \%) & $68(8.6)$ & $46(7.1)$ & $22(15.9)$ & 0.001 \\
\hline \multicolumn{5}{|c|}{ Laboratory parameters and echocardiography } \\
\hline Lymphocyte, $\left(10^{3} / \mu \mathrm{L}\right)$ & $2.1(1.9-2.7)$ & $2.2(2.0-2.7)$ & $2.1(1.9-2.2)$ & 0.025 \\
\hline Platelets, $\left(10^{3} / \mu \mathrm{L}\right)$ & $240(200-286)$ & $241(203-287)$ & $232(195-273)$ & 0.065 \\
\hline Total cholesterol (mg/dL) & $205(182-240)$ & $205(179-235)$ & $216(187-252)$ & 0.084 \\
\hline LDL-C (mg/dL) & $149(125-174)$ & $144(121-172)$ & $157(131-193)$ & $<0.001$ \\
\hline $\mathrm{HDL}-\mathrm{C}(\mathrm{mg} / \mathrm{dL})$ & $40(34-44)$ & $40(35-44)$ & $35(32-40)$ & $<0.001$ \\
\hline Triglyceride (mg/dL) & $167(128-202)$ & $165(127-206)$ & 170 (151-199) & 0.051 \\
\hline Serum creatinine $(\mathrm{mg} / \mathrm{dL})$ & $0.81(0.71-0.94)$ & $0.80(0.67-0.91)$ & $0.9(0.8-1.0)$ & $<0.001$ \\
\hline Urea $(\mathrm{mg} / \mathrm{dL})$ & $32(28-36)$ & $32(28-36)$ & $36(34-39)$ & $<0.001$ \\
\hline Sodium (mEq/L) & $137(133-142)$ & $137(133-142)$ & $137(135-141)$ & 0.678 \\
\hline
\end{tabular}

association disappeared after adjustment for other cardiovascular risk factors. We found that the presence of LAFB has no independent role in predicting obstructive LM and/or pLAD lesions. Therefore, it should be considered a marker rather than a determinant of LM and/or pLAD lesions in patients with suspected stable angina pectoris.

In previous studies, the presence of LAFB differed when evaluated in different groups. In the general population, the prognostic implications of LAFB have been examined in studies with inconsistent results. Miller et al. (14) demonstrated that patients with LAFB had the poorest outcome among patients with uncomplicated ventricular conduction blocks, and emphasized that LAFB is a significant predictor of mortality. Conversely, other epidemiological studies suggested that isolated LAFB may not have adverse prognostic implications $(12,20,21)$. Biagini et al. (13) concluded that LAFB is associated with an increased risk of cardiac death in patients with suspected CAD referred for dobutamine stress echocardiography. Similarly, as a recent study revealed that the presence of LAFB is related to an increased risk of all-cause death when compared with isolated RBBB in patients without apparent ischemic heart disease (22). In another study conducted in patients with no evidence of cardiac disease, investigators found a significant association between LAFB, and hypertension orcardiac disease (11).

Although LAFB has many etiologies, one of the most important causes is CAD (15). Previous studies have shown that high-grade narrowing of the LAD coronary artery can induce the development of LAFB (23-26). Assali et al. (23) reported that patients in whom LAFB develops during inferior wall acute myocardial infarction have a higher prevalence of stenosis in the LAD coronary artery. Lévy et al. (24) found that LAFB is associated with significant stenosis of the LAD coronary artery in patients with significant CAD at ICA. In another study, the same clinicians also showed that transient LAFB during an attack of angina pectoris may be indicative of a severe obstruction of the LAD coronary artery in the vicinity of the first perforator (25). It has been shown that selective opacification of the left coronary artery can cause transient left anterior hemiblock (26). 
Table 3. Demographic, clinical, laboratory, and angiographic characteristics of study patients according to the presence of LAFB

\begin{tabular}{|c|c|c|c|c|c|c|c|}
\hline \multirow[b]{2}{*}{ Baseline characteristics } & \multirow[b]{2}{*}{ All patients $(n=790)$} & \multicolumn{3}{|l|}{ Before matching } & \multicolumn{3}{|l|}{ After matching } \\
\hline & & LAFB $-(n=722)$ & $\mathrm{LAFB}+(n=68)$ & p & LAFB $-(n=68)$ & $\mathrm{LAFB}+(n=68)$ & p \\
\hline Age (years) & $58(50-65)$ & $58(50-64)$ & $62(56-69)$ & 0.002 & $61(51-68)$ & $62(56-69)$ & 0.433 \\
\hline Male gender, $\mathrm{n}(\%)$ & $532(67.3)$ & $480(66.5)$ & $52(76.5)$ & 0.093 & $54(79.4)$ & $52(76.5)$ & 0.679 \\
\hline Diabetes mellitus, $n$ (\%) & $256(32.4)$ & $228(31.6)$ & $30(44.1)$ & 0.076 & $21(30.9)$ & $30(44.1)$ & 0.111 \\
\hline Current smoking, n (\%) & $310(39.2)$ & 278 (38.5) & $32(47.1)$ & 0.167 & $38(55.9)$ & $32(47.1)$ & 0.303 \\
\hline Hypertension, n (\%) & $240(30.4)$ & $214(29.6)$ & $24(35.3)$ & 0.141 & $19(27.9)$ & $24(35.3)$ & 0.356 \\
\hline Dyslipidemia, n (\%)* & $452(57.2)$ & $404(56)$ & 48 (70.6) & 0.020 & $43(63.2)$ & 48 (70.6) & 0.380 \\
\hline Family history of CAD, $n(\%)$ & $240(30.4)$ & $212(29.4)$ & $28(41.2)$ & 0.043 & $18(26.5)$ & $28(41.2)$ & 0.120 \\
\hline $\mathrm{BMI}\left(\mathrm{kg} / \mathrm{m}^{2}\right)$ & $29.4(27-33.7)$ & $29.4(26.6-33.8)$ & $29.8(27.8-33.2)$ & 0.244 & $28.7(25.4-30.4)$ & $29.8(27.8-33.2)$ & 0.002 \\
\hline $\mathrm{BSA}\left(\mathrm{m}^{2}\right) \dagger$ & $1.96(1.85-2.07)$ & $1.95 \pm 0.15$ & $1.96(1.87-2.10)$ & 0.500 & $1.97(1.83-2.07)$ & $1.96(1.87-2.10)$ & 0.449 \\
\hline \multicolumn{8}{|c|}{ Laboratory parameters and echocardiography } \\
\hline Hemoglobin (g/dL) & $14.8(13.5-15.8)$ & $14.8(13.5-16)$ & $14.7(13.8-15.4)$ & 0.435 & $15.1(13.5-16.1)$ & $14.7(13.8-15.4)$ & 0.146 \\
\hline WBC $\left(10^{3} / \mu \mathrm{L}\right)$ & $7.7(6.4-9.2)$ & $7.8(6.5-9.2)$ & $7.65(6-9)$ & 0.762 & $8.1(7.6-10.4)$ & $7.65(6-9)$ & 0.052 \\
\hline Neutrophil, $\left(10^{3} / \mu \mathrm{L}\right)$ & $4.2(3.5-5.1)$ & $4.2(3.5-5.1)$ & $4.3(3.4-5.2)$ & 0.715 & $4.95(3.7-6.0)$ & $4.3(3.4-5.2)$ & 0.008 \\
\hline Lymphocyte, $\left(10^{3} / \mu \mathrm{L}\right)$ & $2.1(1.9-2.7)$ & $2.1(1.9-2.7)$ & $2.0(1.7-2.5)$ & 0.021 & $2.2(2.1-3.0)$ & $2.0(1.7-2.5)$ & 0.055 \\
\hline Platelets, $\left(10^{3} / \mu \mathrm{L}\right)$ & $240(200-286)$ & $240(200-286)$ & 251 (198-294) & 0.636 & $271(232-299)$ & 251 (198-294) & 0.011 \\
\hline Total cholesterol (mg/dL) & $205(182-240)$ & $205(184-236)$ & $217(166-249)$ & 0.080 & $212(182-240)$ & $217(166-249)$ & 0.670 \\
\hline LDL-C (mg/dL) & $149(125-174)$ & $149(125-174)$ & $156(133-183)$ & 0.110 & $133(128-167)$ & $156(133-183)$ & 0.356 \\
\hline $\mathrm{HDL}-\mathrm{C}(\mathrm{mg} / \mathrm{dL})$ & $40(34-44)$ & $40(34-44)$ & $37(33-40)$ & 0.056 & $36(32-44)$ & $37(33-40)$ & 0.807 \\
\hline Triglyseride (mg/dL) & $167(128-202)$ & $167(131-202)$ & $171 \pm 76$ & 0.557 & $154(138-203)$ & $171 \pm 76$ & 0.848 \\
\hline Serum creatinine (mg/dL) & $0.81(0.71-0.94)$ & $0.81(0.70-0.94)$ & $0.84(0.72-0.95)$ & 0.249 & $0.9(0.7-1.0)$ & $0.84(0.72-0.95)$ & 0.454 \\
\hline Urea (mg/dL) & $32(28-36)$ & $32(28-36)$ & $32(28-37)$ & 0.541 & $32(28-35)$ & $32(28-37)$ & 0.190 \\
\hline Sodium (mEq/L) & $137(133-142)$ & $137(133-142)$ & $137(132-141)$ & 0.101 & $136(132-140)$ & $137(132-141)$ & 0.958 \\
\hline Potassium (mEq/L) & $4.4(3.8-5.0)$ & $4.4(3.8-5.0)$ & $4.4(3.9-4.9)$ & 0.657 & $4.4(3.9-4.9)$ & $4.4(3.9-4.9)$ & 0.944 \\
\hline LVEF (\%) & $63(60-65)$ & $63(60-65)$ & $65(62-66)$ & 0.070 & $65(60-68)$ & $65(62-66)$ & 0.840 \\
\hline LV mass (g) & $192(169-227)$ & $187(166-227)$ & $227(210-248)$ & $<0.001$ & $192(170-241)$ & $227(210-248)$ & 0.001 \\
\hline $\operatorname{LVMI}\left(\mathrm{g} / \mathrm{m}^{2}\right)$ & $97(85-116)$ & $95(83-113)$ & $112(104-129)$ & $<0.001$ & $97(85-114)$ & $112(104-129)$ & $<0.001$ \\
\hline \multicolumn{8}{|l|}{ Angiographic characteristics } \\
\hline Normal, n (\%) & $184(23.3)$ & $168(23.3)$ & $16(23.5)$ & 0.961 & $4(5.9)$ & $16(23.5)$ & 0.110 \\
\hline Mild CAD, n (\%) & $288(36.5)$ & $268(37.1)$ & $20(29.4)$ & 0.207 & $40(58.8)$ & $20(29.4)$ & 0.001 \\
\hline Significant CAD, n (\%) & $318(40.3)$ & $286(39.6)$ & $32(47.1)$ & 0.231 & $24(35.3)$ & $32(47.1)$ & 0.163 \\
\hline - LAD, n (\%) & $216(27.3)$ & $186(25.8)$ & $30(44.1)$ & 0.001 & $16(23.5)$ & $30(44.1)$ & 0.011 \\
\hline - CX, n (\%) & $130(16.5)$ & $114(15.8)$ & $16(23.5)$ & 0.100 & $18(26.5)$ & $16(23.5)$ & 0.692 \\
\hline - RCA, n (\%) & $190(24.1)$ & $168(23.3)$ & $22(32.4)$ & 0.094 & $16(23.5)$ & $22(32.4)$ & 0.252 \\
\hline - Single vessel disease, $n(\%)$ & $136(17.2)$ & $126(17.5)$ & $10(14.7)$ & 0.566 & $6(8.8)$ & $10(14.7)$ & 0.287 \\
\hline - Three-vessel disease, $n(\%)$ & $70(8.9)$ & $60(8.3)$ & $10(14.7)$ & 0.076 & $8(11.8)$ & $10(14.7)$ & 0.613 \\
\hline Obstructive CAD, n (\%) & $218(27.6)$ & $188(26)$ & $30(44.1)$ & 0.001 & $20(29.4)$ & $30(44.1)$ & 0.075 \\
\hline - PCl, n (\%) & $146(18.5)$ & $130(18)$ & $16(23.5)$ & 0.262 & $16(23.5)$ & $16(23.5)$ & 1.000 \\
\hline - CABG, n (\%) & $60(7.6)$ & $46(6.4)$ & $14(20.6)$ & $<0.001$ & $4(5.9)$ & $14(20.6)$ & 0.011 \\
\hline - OMT alone, n (\%) & $12(1.5)$ & $12(1.7)$ & 0 & 0.284 & $2(2.9)$ & 0 & 0.154 \\
\hline $\begin{array}{l}\text { Obstructive LM and/or pLAD } \\
\text { lesion, } n(\%)\end{array}$ & $138(17.5)$ & $116(16.1)$ & $22(32.2)$ & 0.001 & $8(11.8)$ & $22(32.2)$ & 0.004 \\
\hline SYNTAX score & $0(0-8)$ & $0(0-7)$ & $3(0-21)$ & 0.053 & $0(0-4)$ & $3(0-21)$ & 0.073 \\
\hline - Low (0-22), n (\%) & $682(86.3)$ & $630(87.3)$ & $52(85.3)$ & 0.013 & $60(88.2)$ & $52(85.3)$ & 0.072 \\
\hline - Intermediate (23-32), n (\%) & $66(8.4)$ & $56(7.8)$ & $6(8.8)$ & 0.048 & $4(5.9)$ & $6(8.8)$ & 0.090 \\
\hline - High (>32), n (\%) & $42(5.3)$ & $36(5)$ & $8(9.5)$ & 0.178 & $4(5.9)$ & $8(9.5)$ & 0.511 \\
\hline $\begin{array}{l}\text { BMI: Body mass index, BSA: Body } \\
\text { cholesterol, LAD: Left anterior des } \\
\text { and/or pLAD: Left main coronary } \\
\text { medical therapy, PCI: Percutaneo } \\
\text { National Health and Nutrition Ex }\end{array}$ & $\begin{array}{l}\text { a, CABG: Coronary ar } \\
\text { ronary artery, LAFB: } \\
\text { or proximal left ante } \\
\text { intervention, WBC: } \\
\text { inrvey III data, } † \text { : Calc }\end{array}$ & $\begin{array}{l}\text { ass graft, CAD: Co } \\
\text { rior fascicular blo } \\
\text { cending coronary } \\
\text { ood cell, * : The pr } \\
\text { according to the D }\end{array}$ & $\begin{array}{l}\text { y artery disesae, } \\
\text { CC: Left domina } \\
\text {, LVEF: Left vent } \\
\text { e of dyslipidemi } \\
\text { method }\end{array}$ & umfle & $\begin{array}{l}\text { onary artery, HD } \\
\text { ation, LDL-C: Lou } \\
\text { cition, LVMI: Left } \\
\text { rding to age- an }\end{array}$ & $\begin{array}{l}\text { gh-density lipopr } \\
\text { ty lipoprotein ch } \\
\text { cular mass index, } \\
\text { er-adjusted perce }\end{array}$ & $\begin{array}{l}\text { rol, LM } \\
\text { Optimal } \\
\text { from }\end{array}$ \\
\hline
\end{tabular}


Table 4. Predictors of patients with obstructive coronary artery disease and LM and/or pLAD lesion

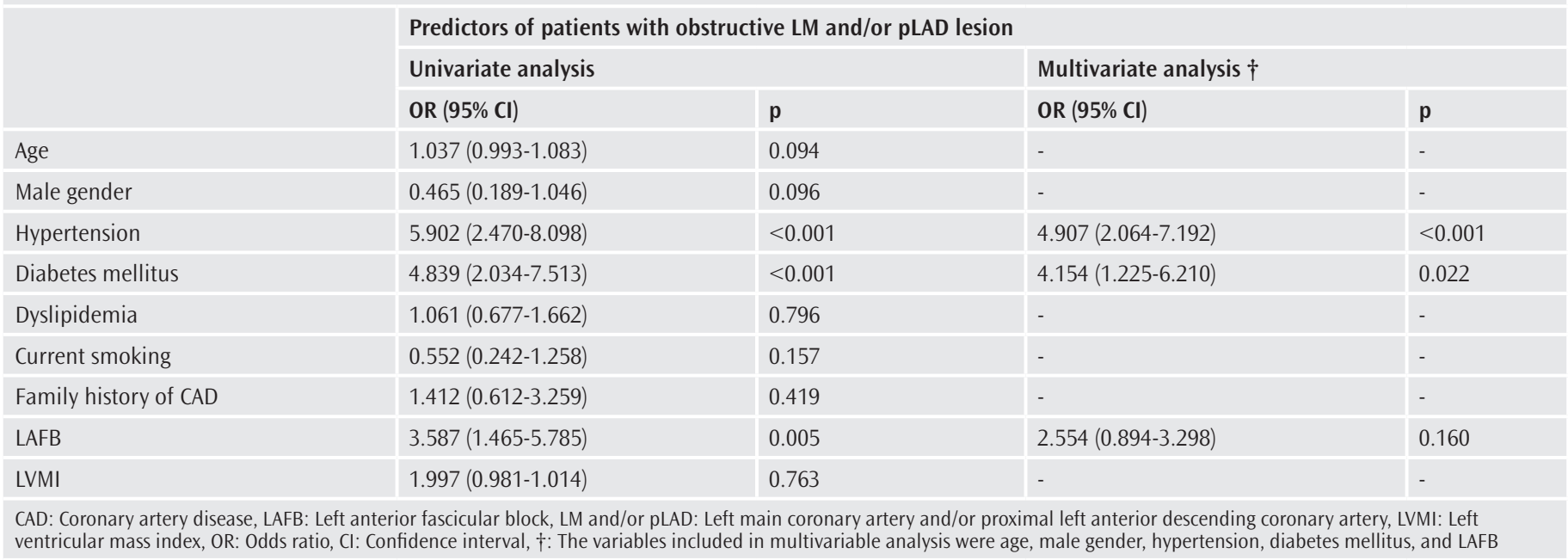

It is difficult to distinguish between a left axis deviation caused by LAFB and that caused by LVH. In general, LVH does not shift the axis more leftward than -30 degrees. However, these two situations may overlap. Our results indicate that LVMI was higher in the LAFB group. In addition, LAFB prevalence was highest in patients with severely abnormal LVMI. LVH is associated with coronary heart disease mortality and hypertension (27). Moreover, as LVH advances, the deterioration in coronary microvascular circulation (28) can cause conduction abnormality in the left anterior fascicle, which is very sensitive to ischemia. Hypertension is an important cause of increased LVMI and the presence of LAFB. These two clinical parameters, which have a significant but not an independent predictive value in our study, are indirect markers that reflect the role of hypertension in CAD. However, the left conduction system structure is more complex and variable than the simplified trifascicular structure. This may be why an obstructive LM and/or pLAD lesions were not directly and independently associated to LAFB.

DM is a major risk factor for CAD with increasing prevalence. It is also associated with increased LVM and interstitial and perivascular fibrosis (29). Therefore, cardiomyopathy and LVH are two other DM-associated abnormalities in cardiovascular function. There is paucity of data on the relationship between DM and cardiac conduction system disorders. Jeong et al. studied 14,540 patients and found that DM is independently associated with RBBB, but not LBBB (30). In another study, García Rubí and Baduí Dergal (31). detected a high prevalence of bifascicular block among patients with diabetes. Although the increased prevalence of LBBB in patients with DM was not reported, the presence of LBBB in DM indicates advanced cardiovascular involvement and CAD complexity $(32,33)$. In our study, DM was more prevalent in the group with LAFB. This could reveal the direct effect of diabetes on atherosclerosis or LVH. Another possible theory suggests that autonomic neuropathy is another complication in patients with diabetes associated with the emergence of LAFB in this group. However, the evidence for such an association is lacking; therefore, more research is necessary to ascertain this relationship.

\section{Study Limitations}

Our study has several limitations. The study was conducted with a relatively small sample. In addition, CAD was only evaluated through visual interpretation.

\section{Conclusion}

LAFB is associated with known cardiovascular risk factors, but it acts as a marker rather than a determinant of obstructive LM and/or pLAD lesions in patients with stable angina pectoris. The significantly increased prevalence of obstructive LM and/or pLAD lesions in patients with LAFB might be due to an increased prevalence in hypertension and DM, but there is a need larger studies to ascertain this finding. Nevertheless, LAFB is not frequently a "normal variant," and the presence of LAFB might help to identify obstructive LM and/or pLAD lesions in patients with suspected stable angina pectoris. Thus, physicians should have a low threshold for further cardiac evaluation if symptoms suggesting CAD are present.

Ethics Committee Approval: The approval form the the Clinical Research Ethics Committee of University of Health Sciences Turkey, Kanuni Sultan Süleyman Training and Research Hospital was obtained (approval number: 2020/62, date: 12.11.2020).

Informed Consent: Informed consent was granted by all patients before enrollment.

Peer-review: Externally and internally peer-reviewed.

Authorship Contributions: Surgical and Medical Practices - Ö.F.Ç., S.Ş.; Concept - Ö.F.C., S.Ş.; Design - Ö.F.Ç., A.S.Y.; Data Collection or Processing - Ö.F.Ç., S.S.; Analysis or Interpretation - Ö.F.Ç., S.S., A.S.Y.; Literature Search - Ö.F.C., A.S.Y.; Writing - Ö.F.C., A.S.Y.

Conflict of Interest: No conflict of interest was declared by the authors.

Financial Disclosure: The authors declared that this study received no financial support.

\section{References}

1. Benjamin EJ, Muntner P, Alonso A, Bittencourt MS, Callaway CW, Carson AP; American Heart Association Council on Epidemiology and Prevention 
Statistics Committee and Stroke Statistics Subcommittee. Heart Disease and Stroke Statistics-2019 Update: A Report From the American Heart Association. Circulation 2019; 139: e56-528.

2. Cassar A, Holmes D, Charanjit S, Gersh B. Chronic coronary artery disease: diagnosis and management. Mayo Clin Proc 2009; 84: 1130-46.

3. Tarkin JM, Kaski JC. Pharmacological treatment of chronic stable angina pectoris. Clin Med 2013; 13: 63-70.

4. May O, Schlosser H, Skytte L. A high pressure predicts bleeding complications and a longer hospital stay after elective coronary angiography using the femoral approach. J Interv Cardiol 2009; 22: 175-8.

5. Knuuti J, Wijns W, Saraste A, Capodanno D, Barbato E, Funck-Brentano C, et al; ESC Scientific Document Group. 2019 ESC Guidelines for the diagnosis and management of chronic coronary syndromes. Eur Heart J 2020; 41: 407-77.

6. Patel MR, Peterson ED, Dai D, Brennan JM, Redberg RF, Anderson HV, et al. Low diagnostic yield of elective coronary angiography. N Eng J Med 2010; 362: 886-95

7. Rosenbaum MB, Elizari MV, Lázzari JO. Los Hemibloqueos. Buenos Aires: Paidos; 1968.

8. Rosenbaum MB, Elizari MV, Lázzari JO. The hemiblocks. Oldsmar, Flor: Tampa Tracings; 1970.

9. Oliveros RA, Seaworth J, Weiland FL, Boucher CA. Intermittent left anterior hemiblock during treadmill exercise test: correlation with coronary arteriogram. Chest 1977; 72: 492-4.

10. Boran KJ, Oliveros RA, Boucher CA, Beckmann CH, Seaworth JF. Ischemiaassociated intraventricular conduction disturbances during exercise testing as a predictor of proximal left anterior descending coronary artery disease. Am J Cardiol 1983; 51: 1098-102.

11. Corne RA, Beamish RE, Rollwagen RL. Significance of left anterior hemiblock. Br Heart J 1978; 40: 552-7.

12. Yano K, Peskoe SM, Rhoads GG, Moore JO, Kagan A. Left axis deviation and left anterior hemiblock among 8,000 Japanese-American men. Am J Cardiol 1975; 35: 809-15.

13. Biagini E, Elhendy A, Schhinkel FL, Nelwan S, Rizzello V, van Domburg RT, et al. Prognostic significance of left anterior hemi-block in patients with suspected coronary artery disease. J Am Coll Cardiol 2005; 46: 858-63.

14. Miller WL, Hodge DO, Hammill SC. Association of uncomplicated electrocardiographic conduction blocks with subsequent cardiac morbidity in a community-based population (Olmsted County, Minnesota). Am J Cardiol 2008; 101: 102-6.

15. Elizari MV, Acunzo RS, Ferreiro M. Hemiblocks revisited. Circulation 2007; 115: 1154-63.

16. Surawicz B, Childers R, Deal BJ, Gettes LS, Bailey JJ, Gorgels A, et al; American Heart Association Electrocardiography and Arrhythmias Committee, Council on Clinical Cardiology; American College of Cardiology Foundation; Heart Rhythm Society. AHA/ACCF/HRS recommendations for the standardization and interpretation of the electrocardiogram: part III: intraventricular conduction disturbances: a scientific statement from the American Heart Association Electrocardiography and Arrhythmias Committee, Council on Clinical Cardiology; the American College of Cardiology Foundation; and the Heart Rhythm Society. Endorsed by the International Society for Computerized Electrocardiology. J Am Coll Cardiol 2009; 53: 976-81.

17. Lang RM, Bierig M, Devereux RB, Flachskampf FA, Foster E, Pellikka $\mathrm{PA}$, et al; Chamber Quantification Writing Group; American Society of Echocardiography's Guidelines and Standards Committee; European Association of Echocardiography. Recommendations for chamber quantification: a report from the American Society of Echocardiography's Guidelines and Standards Committee and the Chamber Quantification Writing Group, developed in conjunction with the European Association of Echocardiography, a branch of the European Society of Cardiology. J Am Soc Echocardiogr 2005; 18: 1440-63.

18. Devereux RB, Alonso DR, Lutas EM, Gottlieb GJ, Campo E, Sachs I, et al. Echocardiographic assessment of left ventricular hypertrophy: comparison to necropsy findings. Am J Cardiol 1986; 57: 450-8.

19. Lang RM, Badano LP, Mor-Avi V, Afilalo J, Armstrong A, Ernande L, et al. Recommendations for cardiac chamber quantification by echocardiography in adults: an update from the American Society of Echocardiography and the European Association of Cardiovascular Imaging. J Am Soc Echocardiorg 2015; 16: $233-70$

20. Kulbertus H, De Leval-Rutten F, Dubois M, Petit JM. Prognostic significance of left anterior hemiblock with right bundle branch block in mass screening. Am J Cardiol 1978; 41: 385

21. Rabkin SW, Mathewson FAL, Tate PR. Natural history of marked left axis deviation (left anterior hemiblock). Am J Cardiol 1979; 43: 605-11.

22. Pantazopoulos JS, David A, Kostis WJ, Cosgrove NM, Kostis JB; Myocardial Infarction Data Acquisition System (MIDAS 30) study group. Cardiovascular outcomes in patients with intraventricular conduction blocks: A sixteen-year follow-up in a state-wide database. Hellenic J Cardiol 2017; 58: 194-201.

23. Assali A, Sclarovsky S, Herz I, Solodky A, Sulkes J, Strasberg B. Importance of left anterior hemiblock development in inferior wall acute myocardial infarction. Am J Cardiol 1997; 79: 672-4.

24. Lévy S, Gérard R, Castellanos A Jr, Gharhamani AR, Sommer LS. Pure left anterior hemiblock: hemodynamic and arteriographic aspects in patients with coronary artery disease. Eur J Cardiol 1978; 8: 553-63.

25. Lévy S, Gérard R, Castellanos A Jr, Gharhamani AR, Sommer LS. Transient left anterior hemiblock during angina pectoris: coronagraphic aspects and clinical significance. Eur J Cardiol 1979; 9: 215-25.

26. Rosenbaum M, Shabetai R, Peterson K, O'Rourke RA. Nature of the conduction disturbance in selective coronary arteriography and left heart catheterization. Am J Cardiol 1972; 30: 334-7.

27. Brown DW, Giles WH, Croft JB. Left ventricular hypertrophy as a predictor of coronary heart disease mortality and the effect of hypertension. Am Heart ] 2000; 140: 848-56.

28. Arita Y, Hirata K, Wada N, Komukai K, Tanimoto T, Kitabata H, et al. Altered coronary flow velocity reserve and left ventricular wall motion dynamics: a phenomenon in hypertensive patients with ECG strain. Echocardiography 2013; 30: 634-43.

29. Boudina S, Abel ED. Diabetic cardiomyopathy, causes and effects. Rev Endocr Metab Disord 2010; 11: 31-9.

30. Jeong JH, Kim JH, Park YH, Han DC, Hwang KW, Lee DW, et al. Incidence of and risk factors for bundle branch block in adults older than 40 years. Korean J Intern Med 2004; 19: 171-8.

31. García Rubí DE, Baduí Dergal E. Bifascicular block: long-term follow-up. Report of 40 cases. Arch Inst Cardiol Mex 1982; 52: 31-8.

32. Guzman E, Singh N, Khan IA, Niarchos AP, Verghese C, Saponieri C, et al. Left bundle branch block in type 2 diabetes mellitus: a sign of advanced cardiovascular involvement. Ann Noninvasive Electrocardiol 2004; 9: 362-5.

33. Ozeke O, Aras D, Deveci B, Ozlu MF, Gurel OM, Canga A, et al. Comparison of presence and extent of coronary narrowing in patients with left bundle branch block without diabetes mellitus to patients with and without left bundle branch block but with diabetes mellitus. Am J Cardiol 2006; 97: 857-9. 